\title{
Paleomagnetism of the latest Cretaceous-Paleocene intrusive suite of the Mezcala district, southern Mexico
}

\author{
Roberto S. Molina Garza ${ }^{1}$ and Luis Alva Valdivia ${ }^{2}$ \\ ${ }^{1}$ Centro de Geociencias, Universidad Nacional Autónoma de México, Campus Juriquilla, Querétaro, MEXICO 76230 \\ ${ }^{2}$ Instituto de Geofísica, Universidad Nacional Autónoma de México, Coyoacán, MEXICO 04510
}

(Received January 6, 2006; Revised June 4, 2006; Accepted June 5, 2006; Online published November 8, 2006)

\begin{abstract}
Paleomagnetic data from three plutons of the latest Cretaceous to early Tertiary Mezcala intrusive suite, of the Mezcala mining district in northern Guerrero State, in southern Mexico, are characterized by well-defined near univectorial magnetizations of both normal and reverse polarities. The magnetizations reside primarily in a ferromagnetic cubic phase (magnetite or maghemite) and partly in hematite. Within-site dispersion is relatively small, but between-site dispersion is not. The overall mean for 9 selected sites is of $\mathrm{D}=318.5^{\circ}$ and $\mathrm{I}=47.1^{\circ}\left(\mathrm{k}=18.5 ; \alpha_{95}=12.3^{\circ}\right)$, and is discordant with respect to the reference direction for North America. The discordance may be explained by tilt down-to-the-northeast of the structural block that contains the intrusive suite of about $40^{\circ}$ about a NW-SE trending axis, or perhaps more likely and based on additional geological evidence, by a combination of $\sim 20^{\circ}$ of counterclockwise rotation about a vertical axis and a smaller amount of tilt. Verticalaxis-rotation is supported by paleomagnetic data from nearby localities, whereas a small magnitude of tilt is supported by geological field relations. This result is consistent with the hypothesis that Laramide structures of the Guerrero-Morelos platform were reactivated by a younger deformation event, and that there is a deformation event superimposed that involves lateral slip. The contrasting orientation of NW-SE trending structures within the Mezcala mining district affecting the plutons, and N-S trending Laramide structures, suggests that the discordant paleomagnetic directions are best explained by a combination of tilt and rotation.
\end{abstract}

Key words: Paleomagnetism, Laramide, Guerrero, Mexico.

\section{Introduction}

In southern Mexico there are two relatively recent events of deformation, one linked to the late Cretaceous Laramide orogeny and a younger one linked to strike-slip tectonics and truncation of the Pacific margin; the events are superimposed in the region of the Guerrero-Morelos platform (Fig. 1; Cerca-Martínez et al., 2004; Meschede and Frisch, 1988). Unraveling the structural evolution of this region is thus difficult. Four apparently discrete magmatic pulses from Jurassic (?) to Miocene time affected the region as well, and they provide the means to date and perhaps separate the effects of Laramide from younger tectonic events. A suite of calci-alkaline stocks with associated skarn mineralization intrudes folded Cretaceous strata of the Morelos and Mezcala Formations in northern Guerrero State. The plutons have been associated with a Late Cretaceous volcanic arc formed in response to subduction of the Farallon plate along the western Mexico margin. Emplacement occurred after accretion of the Guerrero terrane or after cessation of Laramide-age compressional deformation (MoránZenteno et al., 1999). The Mezcala granitoids (Fig. 2) are also host to economic Fe and Au mineralization (GonzálezPartida et al., 2003). The main deposits in the Mezcala district currently in exploitation are Filitos, La Agüita and

Copyright (c) The Society of Geomagnetism and Earth, Planetary and Space Sciences (SGEPSS); The Seismological Society of Japan; The Volcanological Society of Japan; The Geodetic Society of Japan; The Japanese Society for Planetary Sciences; TERRAPUB
Nukay; Bermejal is a prospect with 1,000,000 ounces of gold reserves.

Here we present paleomagnetic data for three of the intrusions of the Mezcala district. These data provide the means to recognize and quantify deformation that may be manifest as discordant paleomagnetic directions (Butler, 1992). Declination-only anomalies generally indicate rotations about a vertical axis; a combined anomaly, that is anomalies in both declination and inclination, indicate rotations (tilts) with respect to a horizontal axis; inclination only anomalies can be interpreted as either latitudinal displacement or tilt about a horizontal axis perpendicular to the expected (=observed) declination. If these rotations can be placed in a temporal sequence, the effects of distinct tectonic environments may be recognizable. We thus carried out a paleomagnetic study of the Mezcala intrusive suite in order to establish with reasonable certainty whether or not the plutons record significant deformation related to a late phase of Laramide deformation or a younger deformation event related to strike-slip motion along the southern Mexico Pacific margin. The paleomagnetic method has been applied with relative success to Laramide age intrusions to study the structural history various parts of the western United States (e.g., Melker and Geissman 1997; Hagstrum and Sawyer, 1989).

Strike-slip kinematics in southern Mexico have been related to displacement of the Chortis block along the Pacific margin in mid-Tertiary time (Morán-Zenteno et al., 


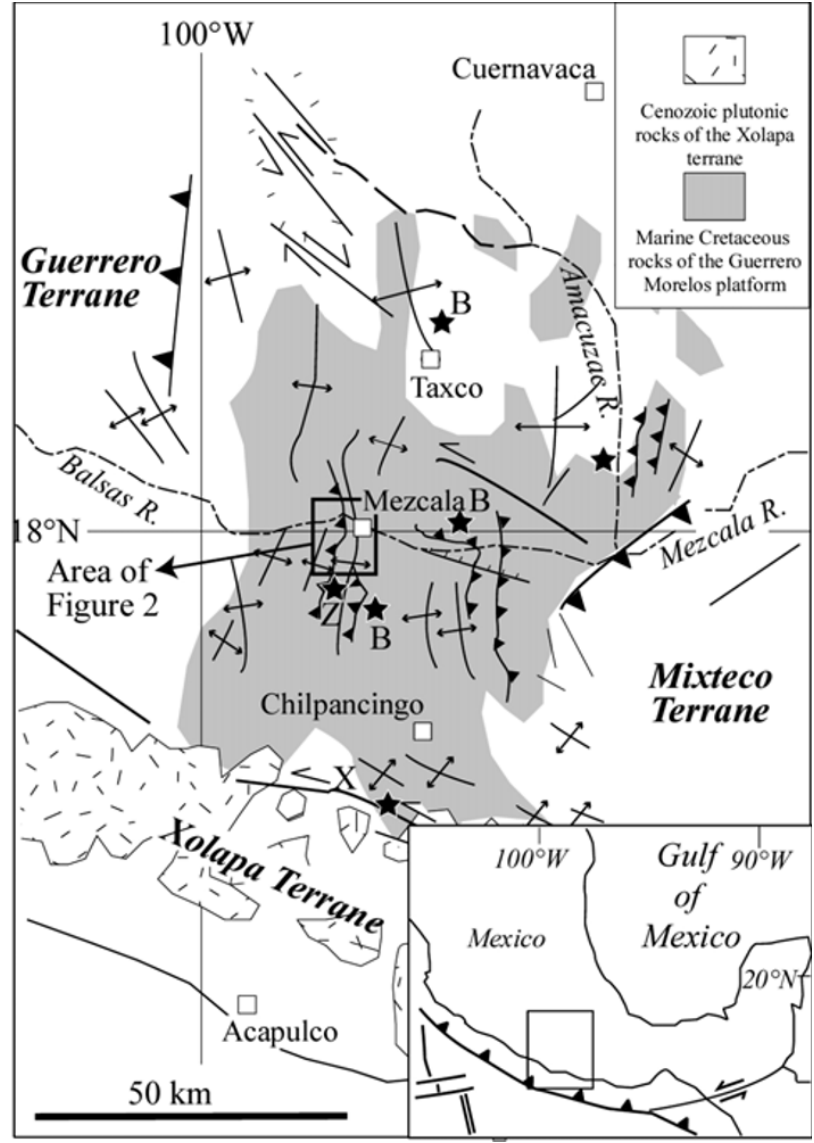

Fig. 1. Simplified tectonic map of southern Mexico showing the location of the Mezcala mining district region. Also included are the trends of the main Laramide structures, the extent of the Guerrero Morelos platform, and Cenozoic plutonic rocks. The map includes tectonostratigraphic terranes in southern Mexico and the location of additional paleomagnetic sampling localities (solid stars) mentioned in the text: $B=$ Balsas Formation; $\mathrm{Z}=$ Zopilote canyon; $\mathrm{X}=$ Xaltianguis.

1999). Because the effects of Laramide deformation and mid-Tertiary strike-slip deformation are superimposed in areas of the Guerrero-Morelos platform, previous studies in Cretaceous rocks have been inconclusive in assigning rotations about a vertical axis to one of the deformation or to both (Molina-Garza et al., 2003). Thus, the study of the Mezcala intrusive suite would allow us to better constrain the timing and mechanism of counterclockwise rotation recorded by synfolding magnetizations in the Morelos and Mezcala Formations, about 20 kilometer south of the Mezcala mining district (Fig. 1). Similarly, paleomagnetic data for the intrusions would allow us to better understand rotations interpreted from data for continental detrital rocks of the Balsas Formation in the Taxco area (UrrutiaFucugauchi, 1983) and concordant directions in the Balsas Formation in other localities of the Morelos-Guerrero platform (Molina-Garza and Ortega-Rivera, 2006). Paleomagnetically determined tilt or rotation might also be a useful tool for exploration and better understanding of the ore deposits.

\section{Geologic Setting}

The Mezcala intrusive suite includes several small bodies, most of them less than about $2 \mathrm{~km}$ in diameter (Fig. 2).

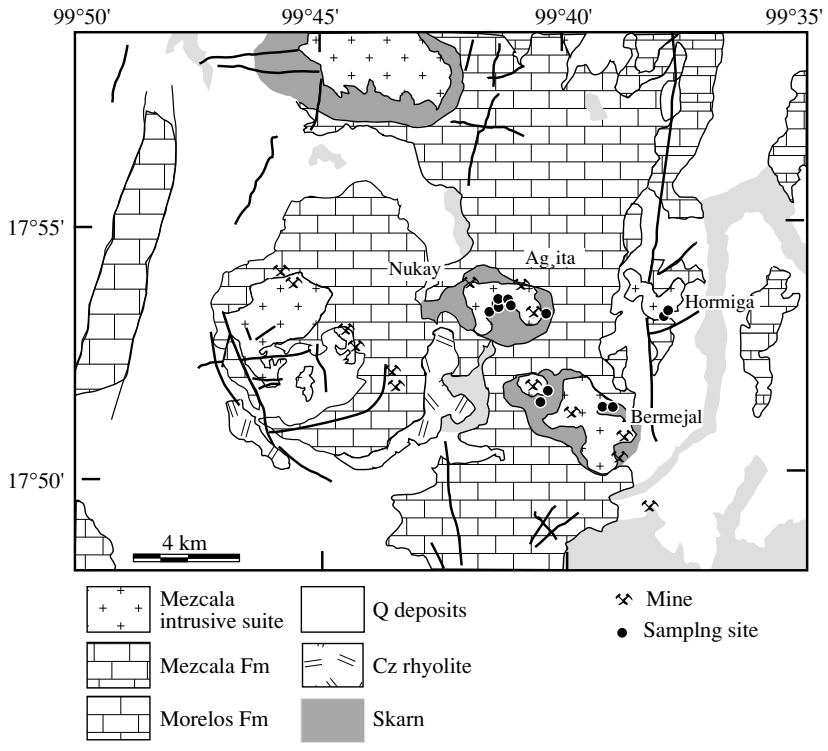

Fig. 2. Simplified geologic map of part of the Mezcala mining district, after Levresse et al. (2004). The locations of all paleomagnetic sampling sites are also given as black circles.

Interpreted volcanic equivalents are the andesites of the Tetelcingo Formation (Ortega-Gutiérrez, 1980; CercaMartínez, 2004). Levresse et al. (2004) reported geochemical data for the intrusive suite, mineral alteration zone, and ore bodies; these authors also published U-Pb dates for one of the plutons. The intrusions are quartz-porphyr granodiorites, and plutons intrude yet are not offset by $\mathrm{N}$ $\mathrm{S}$ trending, west verging, thrusts thereby suggesting that they postdate compressional deformation. Mineralization occurs as skarns, as well as disseminated within the potassic zone of hydrothermal alteration. Mineralization includes both, botryoidal and massive hematite, and titanomagnetite is a common accessory mineral. De la Garza (1996) and González-Partida et al. (2003) proposed that NW-SE faults served as channelways for both stock emplacement and mineralizing fluid flow. According to Jones and Jackson (1999) mineralization in the district is structurally controlled and is syn-deformational in nature, most commonly in the form of tensional conjugate vein sets. González-Partida et al. (2003) also reported that hematite was trapped in late magmatic fluid inclusions.

Pyroclastic Oligocene age volcanic rocks overlie the intrusive suite and its host rocks. Six concordant zircons from the Nukay stock yield a weighted mean date of $63 \pm 2$, and Levresse et al. (2004) interpreted the age to indicate the time of intrusion. ${ }^{39} \mathrm{Ar}-{ }^{40} \mathrm{Ar}$ data for biotites in iron rich skarn yields dates between 63 and $65 \mathrm{Ma}$ (Jones and Jackson, 1999), suggesting rapid cooling, and/or intrusion at shallow crustal levels. The Paleocene age is in good agreement with previous proposals of a regional post-tectonic pulse of magmatism in the Sierra Madre del Sur (Morán-Zenteno et al., 1999). Plutons are characterized by adakitic signatures (Levresse et al., 2004), and Cerca-Martínez (2004) relate the production of adakites to a model of flat subduction that explains stress transfer across southern Mexico during the Laramide orogeny. Nonethe- 

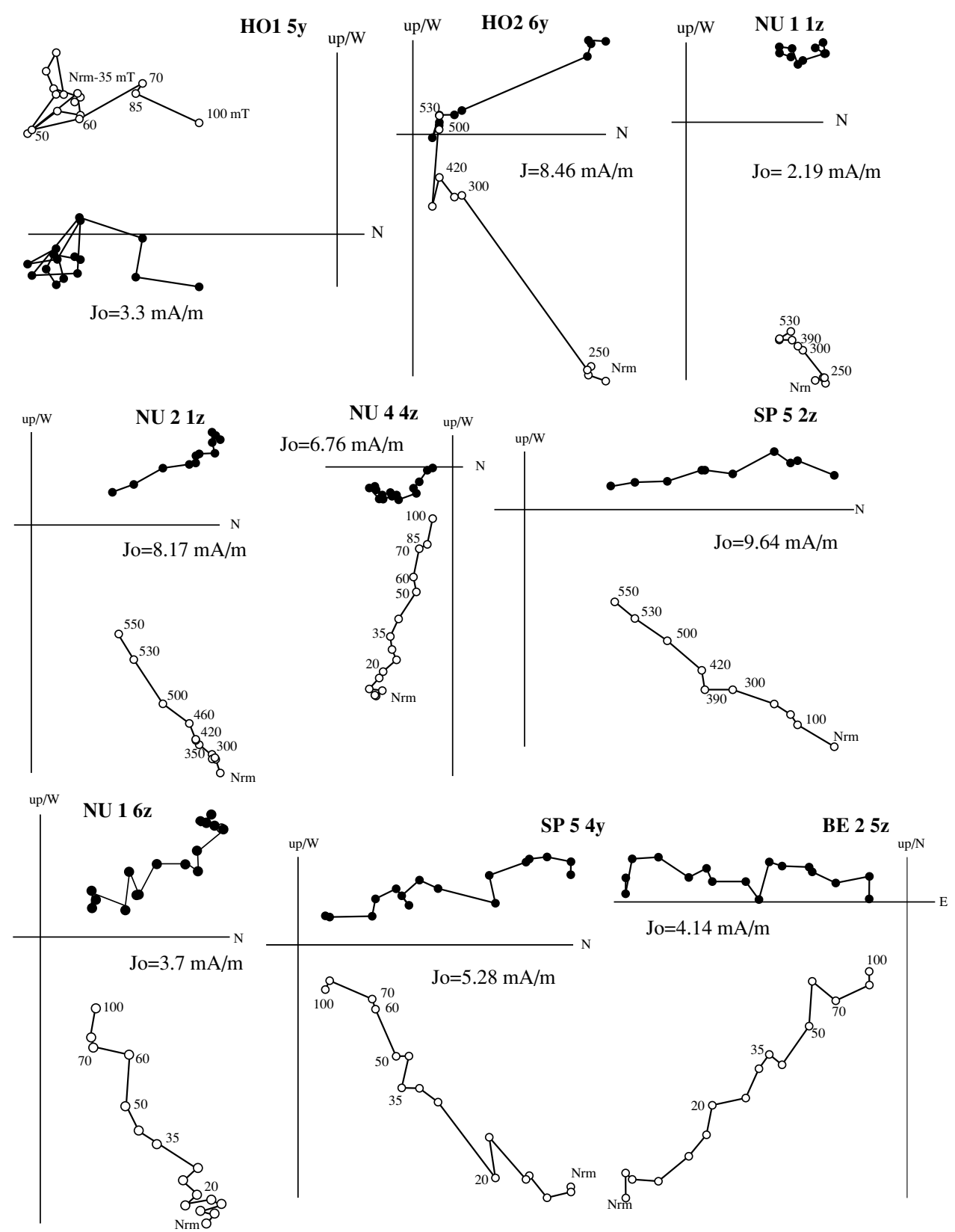

Fig. 3. Orthogonal demagnetization diagrams for selected samples of the Mezcala intrusive suite. Closed (open) symbols are projections on the horizontal (vertical) plane.

less, the plutons themselves could have experienced postLaramide deformation, as associated alteration halos and mineral zonations are somewhat asymmetric with respect to the pluton shape. Skarn deposits are well developed vertically along the plutons contacts with the Morelos Formation, preferably at the WNW-ESE margins. The map of the district also shows northwest-trending lineaments of mines, and the cross section shows west-dipping bodies of massive iron oxides and jasper at the Bermejal mine (Levresse et al., 2004).

The general structure of the Guerrero-Morelos platform, host to the Mezcala intrusive suite, is that of an anticlinorium bordered by, and structurally lower than, two thrust systems oriented north-south, with opposite vergence, to the east and west (Fig. 1). Both major and minor folds axes in the anticlinorium form a complex pattern. The general ori- entation of Laramide structures in the Morelos Formation are notably disturbed in the area north of the Balsas River, where the fold-axes are rotated counterclockwise forming a flower o fan structure. This feature is evident in air photographs and digital elevation models. Interpretations about the origin of this fan include a decollement in the subsurface (de Cserna et al., 1980) or generalized anticlockwise rotation linked to strike-slip displacement (Molina-Garza et al., 2003).

\section{Sampling and Methods}

We collected samples from 18 paleomagnetic sites from three intrusions of the Mezcala intrusive suite and their host rock (Fig. 2). Two sites were collected from the relatively small La Hormiga body, one of them in contact rocks including recrystallized limestone; seven sites were collected 
at the Nukay mine, five at San Pedro mine, one site was collected at the Bermejal mine, and three additional sites were collected from smaller, unmapped intrusions. Samples were drilled in the field using a gas-powered drill, and oriented in situ using magnetic and sun compasses and an inclinometer. Five to seven oriented samples were obtained at each site. In the laboratory, standard $2.1 \mathrm{~cm}$ high specimens were prepared for NRM (natural remanent magnetization) measurements. NRM was measured using a JR5 spinner magnetometer housed in a shielded room at the paleomagnetic laboratories of the Centro de Geociencias and Instituto de Geofísica. All samples were subjected to alternating field (AF) and thermal stepwise demagnetization using commercial equipment. Maximum available induction for AF demagnetization is $100 \mathrm{mT}$, and maximum temperatures used in thermal demagnetization were of $550^{\circ} \mathrm{C}$. Samples were visibly altered and often destroyed during heating experiments, preventing us to reach higher temperatures.

The characteristic magnetization was interpreted from orthogonal demagnetization diagrams (Zijderveld, 1967). Directions were estimated using three-dimensional least square fits (Kirschvink, 1980). Site means and overall means were calculated assuming the directions are reasonably modeled by a Fisher distribution. Deformation of the plutons (tilt or tectonic rotation) was estimated comparing observed and expected directions. The latter were determined using a reference paleomagnetic pole for the North America craton located at $75.2^{\circ} \mathrm{N}-168.4^{\circ} \mathrm{W}$ (calculated from the paleomagnetic database of McElhinny and Lock, 1990). We also compared the results for the Mezcala pluton suite with observed directions in similar age rocks in southern Mexico.

\section{Paleomagnetic Results}

Magnetizations of the intrusions are relatively simple; NRM intensities are moderately high, and can be measured with good precision. Most of the samples have nearly univectorial magnetizations with linear trends to the origin, or linear decay to the origin after removal of a small north directed component interpreted as a viscous overprint (Fig. 3). Occasionally the overprint is more developed, and spurious magnetizations of low coercivity are also locally present. The characteristic magnetization (ChRM) is of relatively high coercivity, with median destructive fields between 35 and $50 \mathrm{mT}$ and maximum coercivities over $100 \mathrm{mT}$. The ChRM is of high discrete laboratory unblocking temperature, greater than $550^{\circ} \mathrm{C}$, but as mentioned above maximum unblocking temperatures could no be determined in most cases because samples were altered during thermal demagnetization experiments.

Isothermal remanence acquisition curves (IRM; Fig. 4) suggest the presence of a soft and a hard magnetic phase. Most of the samples are dominated by the soft phase, which is interpreted to be magnetite, but the presence of hematite is evident in data for recrystalized limestone form the intrusive contact. Hysteresis curves (Fig. 5) indicate that a mixture of multi-domain and pseudo-single domain grains characterizes the intrusions, with a more notable contribution from multi-domain grains in those sites that did not yield well defined magnetizations.

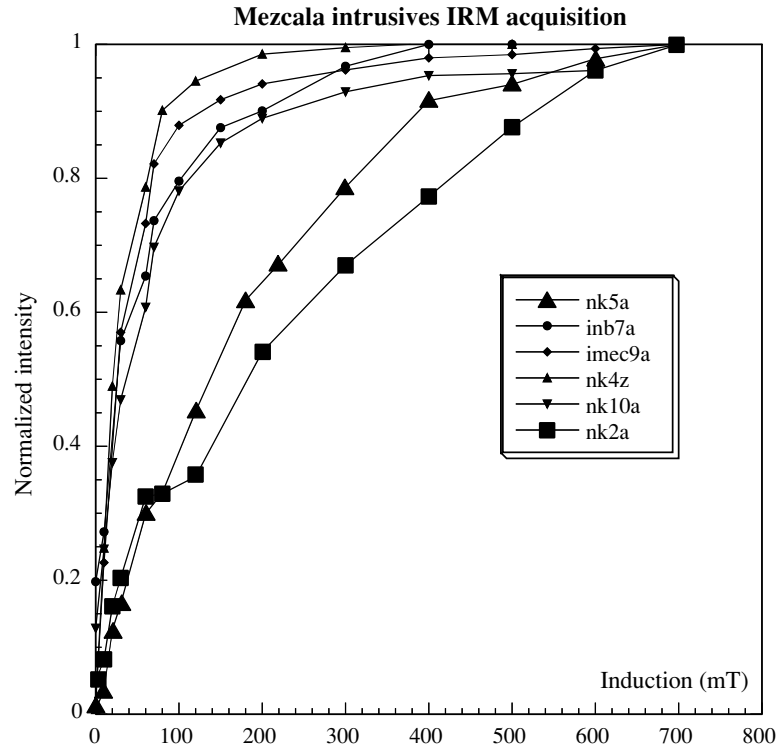

Fig. 4. Normalized IRM acquisition curves of selected samples.

The rock magnetic data, in combination with demagnetization behavior, suggest that the ChRM resides primarily in magnetite, but with small contributions of hematite in some of the samples. The ChRM is of northwest declination and positive inclination. Only site HO1 is of reverse polarity (southeast directed and of negative inclination). Site-means are based on reasonably well-grouped directions, with $\mathrm{k}$ values between about 28 and 240. Some of the means are defined by only four samples and $\alpha_{95}$ values range from $5.3^{\circ}$ to $29.8^{\circ}$. Between-site dispersion is relatively high, and most noticeable is a girdle distribution of site means (Fig. 6). Four sites, all from a relatively small area southeast of the Nukay mine yield anomalously steep southwest-directed magnetizations. These site means are well defined in three of the sites, and demagnetization behavior of these samples is similar to that observed in other sites. Because the sites are relatively close, we infer that they may lie within a large block that has been displaced with respect to its original position either by slumping or by other means. These sites (nu4, n5, icc, and nki) were excluded from the grand mean. Three sites that failed to provide interpretable data in demagnetization experiments were excluded from final calculations. Also, two more sites (nk and imec) were excluded from the overall mean, as they did not yield acceptable statistics. The site mean distribution is somewhat streaked, with declinations varying between $280^{\circ}$ and $350^{\circ}$, and inclination clustered between $30^{\circ}$ and $45^{\circ}$. This distribution suggests that differential rotation between sites may have occurred. There is, however, no clear systematic geographic distribution of declinations; although sites from San Pedro mine appear to be slightly more discordant than other sites. We thus assert that the overall mean reflects the "average" deformation that affected the sampled area.

\section{Data Summary}

Although the number of accepted sites is relatively small, we assume that sampling is sufficient to average paleosec- 

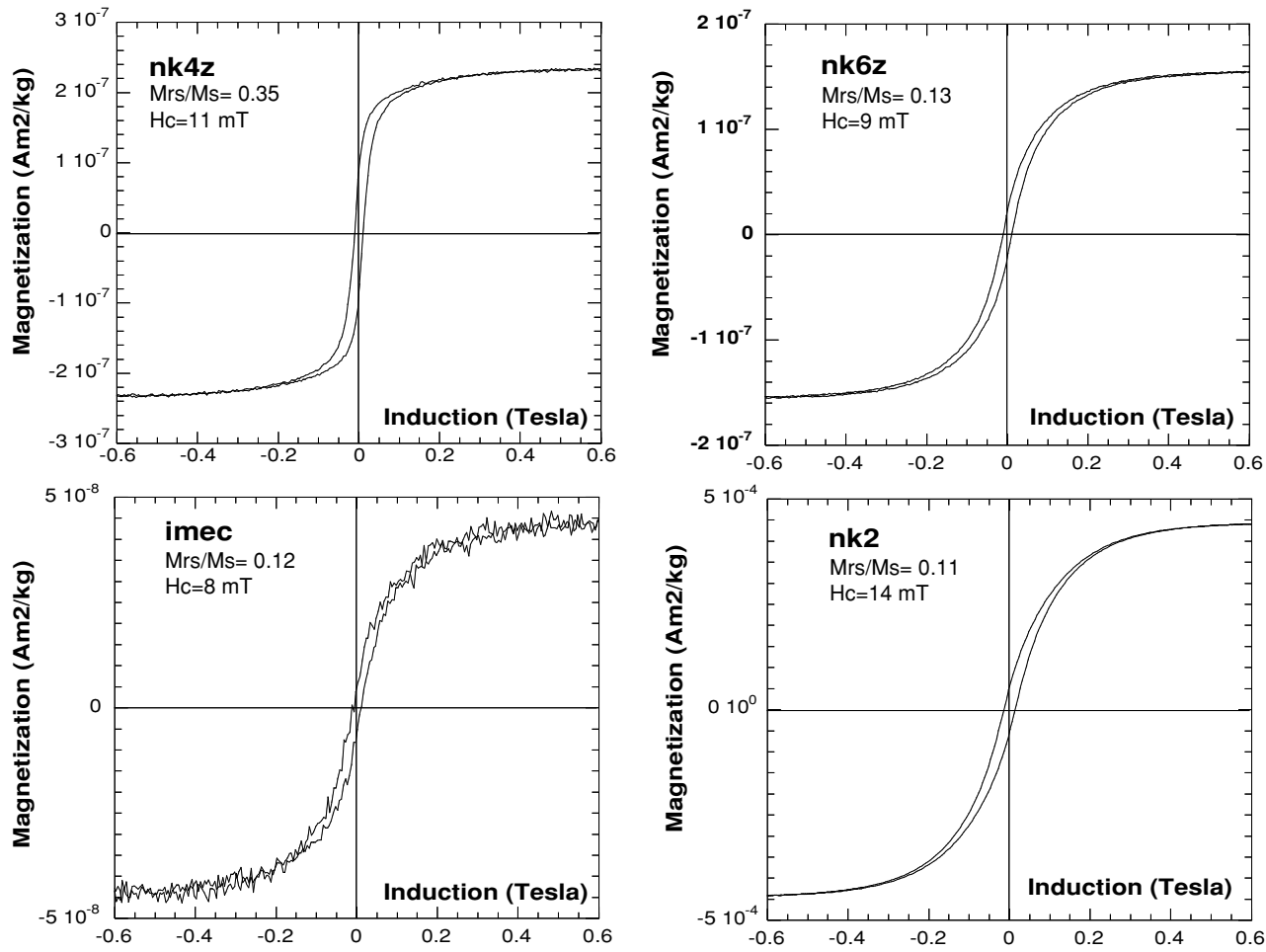

Fig. 5. Examples of hysteresis curves obtained for samples of the Mezcala intrusive suite.

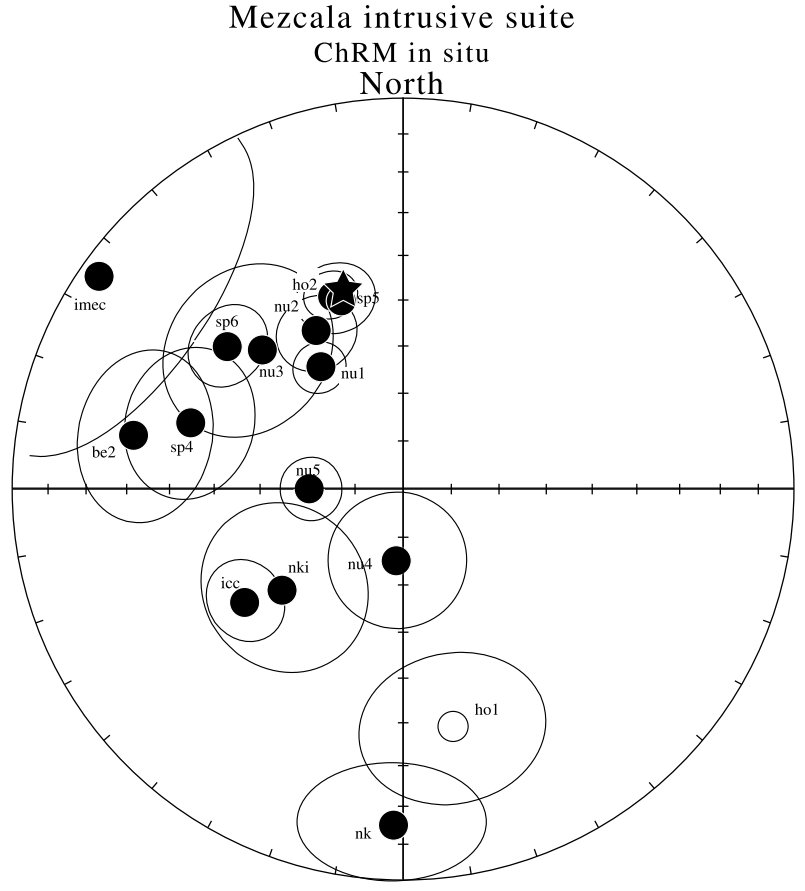

Fig. 6. Equal area projection of site means in in-situ coordinates. Closed (open) symbols are projections on the lower (upper) hemisphere. A star indicates the expected paleomagnetic direction.

ular variation. Our argument is based on the observation of at least one-site recording reverse polarity magnetizations and the interpreted time-span of intrusion emplacement and cooling based on U-Pb and Ar-Ar geochronological data. The sites with anomalously steep directions were excluded from the calculation of an overall mean. The overall mean
Table 1. Paleomagnetic data for the Mezcala intrusive suite.

\begin{tabular}{cccrrr}
\hline Site & $\mathrm{N}$ & $\mathrm{dec}$ & inc & \multicolumn{1}{c}{$\mathrm{k}$} & \multicolumn{1}{c}{$\alpha_{95}$} \\
\hline be2 & 4 & 281.6 & 32.5 & 34.4 & 15.9 \\
ho1 & 4 & 168.4 & -36.8 & 28.4 & 17.5 \\
ho2 & 5 & 340.5 & 46.9 & 97.8 & 7.8 \\
nu1 & 4 & 325.4 & 59.0 & 288.6 & 5.4 \\
nu2 & 5 & 330.9 & 52.3 & 90.0 & 8.1 \\
nu3a & 4 & 311.8 & 45.2 & 27.7 & 17.8 \\
nu4* & 4 & 184.7 & 75.0 & 42.3 & 14.3 \\
nu5* & 4 & 270.1 & 70.8 & 201.3 & 6.5 \\
sp4 & 4 & 287.1 & 41.9 & 40.4 & 14.6 \\
sp5 & 5 & 339.5 & 45.9 & 210.7 & 5.3 \\
sp6 & 3 & 309.3 & 41.5 & 220.6 & 8.3 \\
icc* & 6 & 234.5 & 48.9 & 65.7 & 8.3 \\
nk** & 7 & 181.7 & 14.8 & 15.0 & 15.7 \\
nki* & 7 & 235.7 & 60.4 & 6.5 & 25.7 \\
imec** & 7 & 304.8 & -5.3 & 5.1 & 29.8 \\
Selec. & 9 & 318.5 & 47.1 & 18.5 & 12.3 \\
\hline
\end{tabular}

Here $\mathrm{N}$ is the number of samples used to calculate the mean; dec and inc are the mean declination and inclination and $\mathrm{k}$ and $\alpha_{95}$ are the parameters of the Fisher statistics. Sitess with poor statistics $(* *)$, and sites with steep Inclinations $(*)$ were excluded.

was calculated using both Fisher and Bingham statistics, because the latter are more appropriate to non-symmetric distributions of site means.

Site mean directions are plotted in Fig. 6; paleomagnetic data and statistical parameters are listed in Table 1. The overall mean is of Dec $=318.5$, and Inc $=47.1 \quad(n=9$ sites; $\mathrm{k}=18.5, \alpha_{95}=12.3^{\circ}$; statistics are listed in Table 1 ). The overall mean direction is discordant with respect to the North America reference direction (Fig. 6) in both declination (more westerly) and inclination (steeper). The compar- 

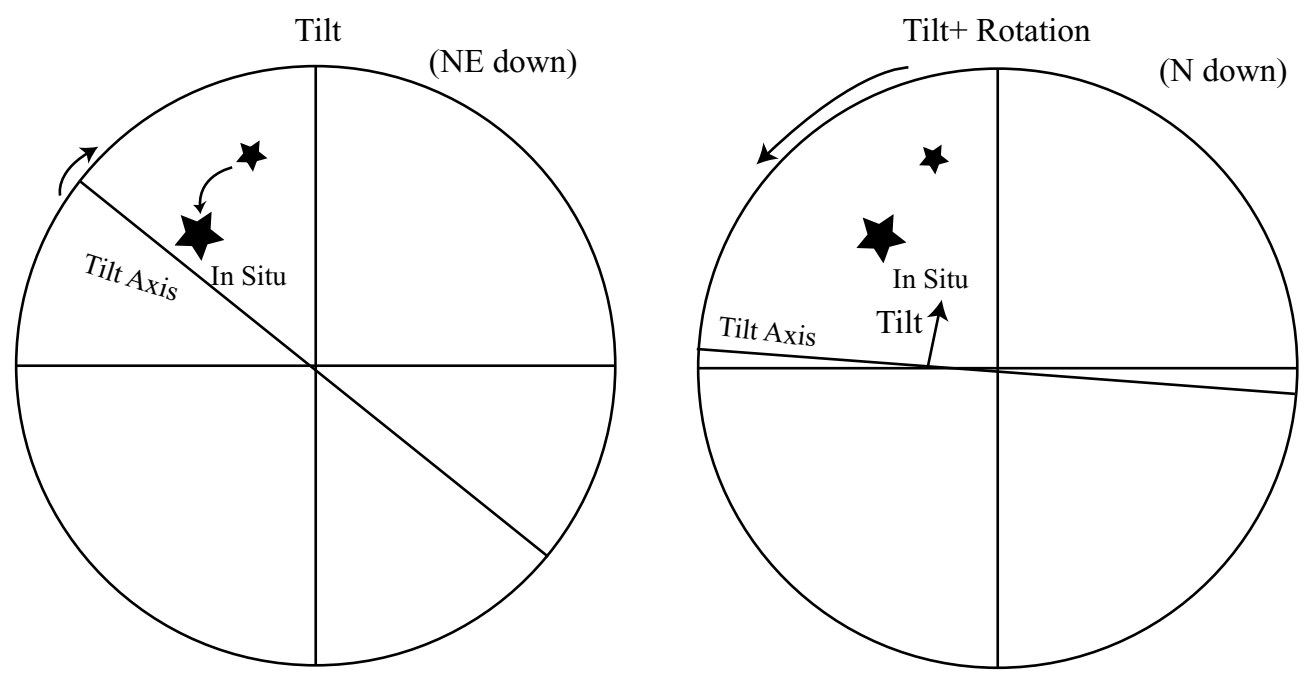

Fig. 7. Schematic model to describe the deformation history (tilt and/or rotation) inferred for the region of Mezcala.

ison of expected and observed directions indicates a rotation of $26^{\circ} \pm 15^{\circ}$ and a flattening value of $16^{\circ} \pm 16^{\circ}$.

\section{Discussion}

The observation of anomalies in both declination and inclination can be best explained by about $40^{\circ}$ of tilt downto-the-northeast about a NW trending axis. The streaked distribution of site means is perpendicular to a NW trend. The interpretation is not unique, and the discordant grand mean direction may also be explained by a combination of a smaller amount of tilt and counterclockwise rotation, as discussed below. Although the intrusions lack paleohorizontal indicators, we note that cross-sections of the mine show west-dipping bodies of massive iron oxides and jasper that one can assume to have an attitude closer to vertical.

Because there is independent evidence for tilt of the plutons, and because previously published paleomagnetic data for southern Mexico rule out latitudinal displacement of this region with respect to North America, we are confident that paleomagnetic data for the Mezcala intrusive suite indicate some magnitude of tilt. Although the paleomagnetic directions can be restored with a simple tilt of $40^{\circ}$ about a NW-SE axis, a combination of a smaller amount of tilt and about $20^{\circ}$ of rotation about a vertical axis seems to be a more likely way to explain the discordant directions. These two models to restore the discordant directions are shown in Fig. 7.

Recently, Molina-Garza et al. (2003) reported paleomagnetic data for the Cretaceous marine sequence (Morelos and Mezcala formations) in the western region of the GuerreroMorelos platform, in localities along Zopilote canyon about $20 \mathrm{~km}$ south of the study area. These authors interpreted the ChRM of the Cretaceous marine sequence as a synfolding magnetization, thus contemporaneous with the Late Cretaceous Laramide deformation. The mean direction observed in the Morelos and Mezcala formations $\left(\mathrm{D}=323.1^{\circ}\right.$, $\mathrm{I}=36.6^{\circ}$ ) was interpreted to indicate about $19^{\circ}$ of counterclockwise rotation of the sampling area. Given the relatively short distance between Zopilote canyon and the Mezcala mining district and the apparent structural continuity

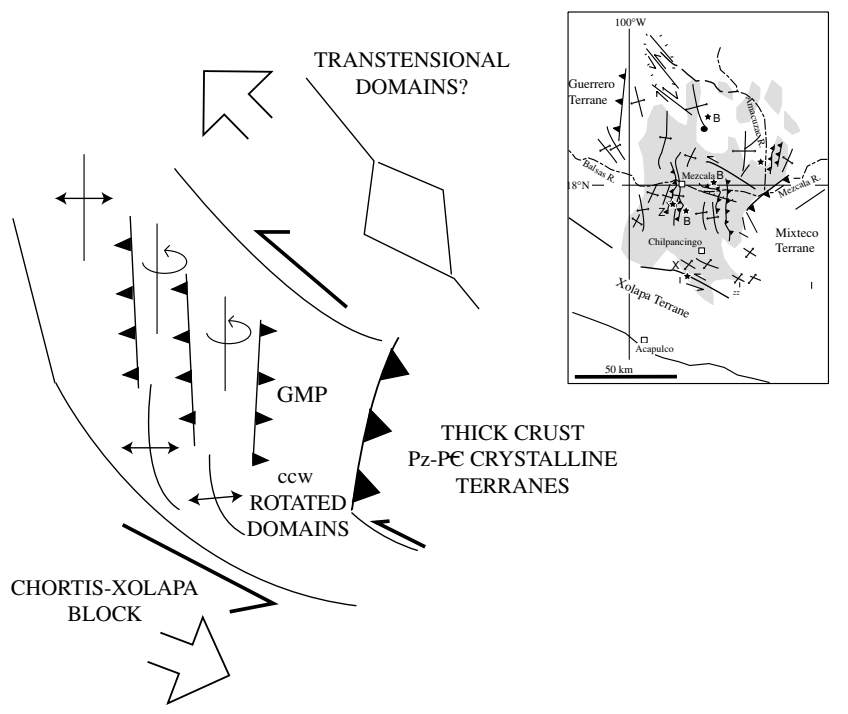

Fig. 8. Idealized model for the mid-Tertiary deformation of the Guerrero-Morelos platform region. See text for further explanation.

between these localities (Cerca-Martínez, 2004), it is likely that at least part of the deformation that affected the Cretaceous marine sequence affected the intrusive suite as well. For instance, a rotation of $20^{\circ}$ about a vertical axis and tilt of $15^{\circ}$ about a NW-SE trending axis can also restore the discordant directions observed in the Mezcala district (Fig. 7).

Molina-Garza et al. (2003) also noted that small to moderate counterclockwise rotation has been paleomagnetically recorded by Cretaceous to Paleogene rocks in nearly all localities studied in southern Mexico in the Guerrero and Xolapa terranes, east of and within the GuerreroMorelos platform (Fig. 8). Inferred rotations average about $15^{\circ}$. In a recent study, Molina-Garza and Ortega-Rivera (2006), demonstrated that upper Eocene strata of the Balsas Formation at two localities in the Guerrero-Morelos plataform record small $\left(-9^{\circ} \pm 8^{\circ}\right)$ to statistically insignificant $\left(+1.2^{\circ} \pm 8^{\circ}\right)$ rotation. The Tierra Caliente intrusion (Xaltianguis) of early Oligocene age is the youngest unit in 
the region that records rotation $\left(-15^{\circ} \pm 23^{\circ}\right.$, counterclockwise), but the result is of relatively low reliability based on a small number of sites (Urrutia-Fucugauchi and MolinaGarza, 1995). A study of the Balsas Formation in a locality north of Taxco (Urrutia-Fucugauchi, 1983; Fig. 1) reports a relatively large rotation in these rocks $\left(18^{\circ} \pm 19^{\circ}\right)$, but again the result is of relatively low reliability as it is also based on a small number of samples. Although more reliable data are needed from upper Tertiary rocks in southern Mexico, we would argue that most rotations had ceased by Oligocene time, after deposition of the Balsas Formation, as indicated by the more reliable data for these rocks at localities on the Guerrero-Morelos platform (Molina-Garza and OrtegaRivera, 2006). This, in turn, would imply that the driving mechanism of the counterclockwise rotation operated from latest Cretaceous to early Oligocene time.

The results for the Mezcala intrusive suite are consistent with the notion that Laramide structures of the GuerreroMorelos platform were reactivated by younger deformation, which involves lateral slip along structures parallel to present Pacific margin of southern mexico such as the Tierra Colorada shear zone. The contrasting orientation of NWSE trending structures within the Mezcala mining district that offset the plutons and N-S trending Laramide structures, suggests that the discordant paleomagnetic directions are best explained by a combination of tilt and rotation. Because the tilt proposed for the Mezcala intrusive suite is consistent with reactivation of the Laramide structures, the observation of tilt and rotation is also consistent with a transpressional setting, as previously proposed by CercaMartínez et al. (2004). Figure 8 shows a model that explains systematic rotation about vertical axes in rocks of the Guerrero-Morelos platform.

The model proposed here implies that the area has been under the influence of a left-lateral shear couple, and that north trending Laramide thrust faults acted as free surfaces that may have accommodated rotation of independent blocks. Rotation would thus be linked to transpression, as has been proposed for this region by Cerca-Martínez (2004). Modest rotation may be accommodated by horizontal slip along strike on the thrust faults or by different degrees of shortening along strike in the thrust faults. Additional rotation may have occurred by fault-drag near the major shear zones (e.g., south of Chilpancingo; Fig. 1).

The subsurface structure of the Guerrero-Morelos platform is unkown, but lateral facies and thickness changes have been proposed (Hernández et al., 1997). Thickness variations of Cretaceous platform rocks and the presence (or absence) of lubricated intervals such as evaporates are likely to have influenced rotation, but to what degree it is presently unknown. We note that both the Zopilote canyon sites and the Mezcala sites, are in the region where the platform gradually deepens to the west, but the effects of the platform structure on the rotation can only be determined with accurate palinspastic reconstructions and more detailed study of facies thickness variations.

\section{Conclusions}

Rocks of the Mezcala intrusive suite yield somewhat dispersed and discordant paleomagnetic directions. The mag- netizations are reasonably well-defined and reside primarily in magnetite. These discordant magnetizations are interpreted in terms of modest tilt and vertical-axes rotations. Overall, rocks of the region of the Guerrero-Morelos platform, in southern Mexico, record counterclockwise rotation about a vertical axes. A model that explains those rotations invokes transpression during the Cenozoic.

Acknowledgments. We thank the help of E. González-Partida and G. Levresse during field sampling. Juan Antonio González assisted in sample preparation and measurements of some of the samples. We also thank John W. Geissman and an anonymous reviewer for their comments. We thank support from DGAPAPAPIIT IN108605.

\section{References}

Butler, R. F., Paleomagnetism: Magnetic Domains to Geologic Terranes, Blackwell Scientific Publications, Cambridge, Massachusetts, 319 pp., 1992.

Cerca-Martínez, M., Deformación y magmatismo Cretácico TardíoTerciario Temprano en la zona de la Plataforma Guerrero Morelos, Ph.D. Thesis, Universidad Nacional Autónoma de México, México, D.F., 175 p, 2004.

Cerca-Martínez, M., L. Ferrari, M. Bonini, G. Corti, and P. Manetti, The role of crustal heterogeneity in controlling vertical coupling during the Laramide shortening and the development of the Caribbean-North American transform in southern Mexico: insights from analogue models, in Vertical coupling and decoupling in the lithosphere, edited by $\mathrm{J}$. Grocott, G. Taylor, and B. Tikoff, Geological Society London, Special Publication, 227, pp. 117-140, 2004.

De Cserna, Z., F. Ortrega-Gutiérrez, and M. Palacios-Nieto, Reconocimiento geológico de la parte central de la cuenca del Alto Río Balsas, Estados de Guerrero y Puebla, Libro Guía, Excursión Geológica III, Reunión Nacional de Geotectónica y Geotermia, México, 40 pp, 1980.

De la Garza, V., R. Téllez, R. Díaz, and A. Hernández, Geology of the Bermejal iron-gold deposit, Mezcala, Guerrero, México, in: Coyner, A. R. and Fahey P. L. (editors), Geology and ore deposits of the American Cordillera, Geological Society of Nevada, Symposium Procedings, Reno, Nevada, 111, pp. 1354-1368, 1996.

González-Partida, E., D. M. Jones, A. Cheilletz, D. Gasquet, and G. Levresse, Paleocene Adakite Bearing Au-Fe Intrusive Rocks, Mezcala México: Evidence from Geochemical Characteristics, Journal of Geochemical Exploration, 26-40, 2003.

Hagstrum, J. T. and D. A. Sawyer, Late Cretaceous paleomagnetism and clockwise rotation of the Silver Bell Mountains, south central Arizona, Journal of Geophysical Research, 94, 17,847-17,860, 1989.

Hernández-Romano, U., N. Aguilera-Franco, M. Martínez-Medrano, and J. Barcel-Duarte, Guerrero-Morelos plataform drowning at the Cenomanian-Turonian boundary, Hutiziltepec area, Guerrero state, southern México, Cretaceous Research, 18, 661-686, 1997.

Jones, D. M. and P. R. Jackson, Geologic setting of skarn associated gold deposits of the Nukay district, Guerrero, Mexico, Asociación Mexicana de Ingenieros de Minas, Metalurgistas y Geólogos de México, XXIII Annual Meeting Proceedings, Acapulco, México-46, 42.

Kirschvink, J. L., The least-squares line and plane and the analysis of paleomagnetic data: examples from Siberia and Morroco, Geophys. J. Roy. astron. Soc., 62, 699-718, 1980.

Levresse, G, E. Gonzalez-Partida, A. Cheilletz, D. Gasquet, E. Deloule, A. Carillo-Chavez, J. Tritlla, and A. Camprubi, Petrology, U/Pb dating and $(\mathrm{C}-\mathrm{O})$ stable isotope constraints on the source and evolution of the adakite-related Mezcala Fe-Au skarn district, Guerrero, Mexico, Mineralium Deposita 39, 301-312, 2004.

McElhinny, M. W. and J. Lock, IAGA global palaeomagnetic database, Geophysical Journal International, 101, 763-766, 1990.

Meschede, M. and W. Frisch, A plate tectonic model for the Mesozoic and early Cenozoic history of the Caribbean plate, Tectonophysics, 296, 269-291, 1988.

Melker, M. D. and J. W. Geissman, Paleomagnetism of the Oquirrh Mountains and implications for the Cenozoic structural history of the easternmost Great Basin, in Geology and Ore Deposits of the Oquirrh and Wasatch Mountains, Utah, Guidebook Series-Society of Economic Geologists, 29, 101-112, 1997.

Molina Garza and Ortega Rivera, Lithostratigraphy, paleomagnetism, and 
magnetostratigraphy of the Balsas Formation, northern Guerrero state, Mexico, Revista Mexicana de Ciencias Geológicas, 23, 215-232, 2006.

Molina Garza, R. S., H. N. Bohnel, and T. Hernández, Paleomagnetism of the Cretaceous Morelos Formations southern Mexico, Tectonophysics, 361, 301-317, 2003.

Morán-Zenteno, D. J., G. Tolson, R. G. Martínez-Serrano, B. Martiny, P. Schaaf, G. Silva-Romo, L. Alva-Aldave, M. S. Hernández-Bernal, and G. N. Solis-Pichardo, Tertiary arc magmatism of the Sierra Madre del Sur, Mexico, and its transition to the volcanic activity of the TransMexican Volcanic Belt, Journal of South American Earth Sciences, 12, 513-535, 1999.

Ortega-Gutiérrez, F., Rocas volcánicas del Maestrichtiano en el área de San Juan Tetelcingo, Estado de Guerrero, in Sociedad Geológica Mexicana, Libro Guía de la Excursión Geológica a la Parte Central de la Cuenca del Alto Río Balsas, V Convención Geológica Nacional, p. 34-38, 1980.
Urrutia-Fucugauchi, J., Preliminary paleomagnetic study of Lower Tertiary volcanic rocks from Morelos and Guerrero states, Geofísica Internacional, 22, 87-110, 1983.

Urrutia-Fucugauchi, J. and R. S. Molina Garza, Magnetic fabrics and rock magnetism of the Xaltianguis intrusive, southern Mexico: implications for emplacement mode, Geofísica Internacional, 34, 201-211, 1995.

Zijderveld, J. D. A., A.C. demagnetization of rocks: Analysis of results, in Methods in Rock Magnetism and Paleomagnetism, edited by D. W. Collinson, K. M. Creer, and S. K. Runcorn, pp. 254-286, Elsevier, Amsterdam, 1967.

R. S. Molina Garza (e-mail: rmolina@geociencias.unam.mx) and L. Alva Valdivia 